\title{
HUBUNGAN POLA ASUH PEMBERIAN MAKAN DAN STATUS EKONOMI DENGAN KEJADIAN BALITA PENDEK
}

\author{
Siti Nur Alfiah ${ }^{1)}$, Ragil Setiyabudi ${ }^{2}$ \\ ${ }^{1}$ Fakultas Ilmu Kesehatan, Universitas Muhammadiyah Purwokerto, Jl. Soepardjo Roestam Km 7 Purwokerto 53181 \\ email: nuralfiah.xiak3@gmail.com \\ ${ }^{2}$ Fakultas Ilmu Kesehatan, Universitas Muhammadiyah Purwokerto, Jl. Soepardjo Roestam Km 7 Purwokerto 53181 \\ email: gilsra@yahoo.co.id
}

\section{Submitted : 07-04-2020, Reviewer:10-04-2020, Accepted: 14-04-2020}

\begin{abstract}
Background: Short stature toddlers is a nutritional problem in Indonesia that has not been resolved because of its high prevalence. The feeding style and economic status are some of the factors that cause the occurrence of short stature children. Objectives: The study aimed to analyze the correlation between feeding style and economic status with the occurence of short stature toddlers aged 0-24 months in Gunungwetan Village, Jatilawang Public Health Center, Banyumas Regency. Methods: This study used an analytic survey method with a case-control approach. The number of samples used in this study were 106 respondents consisting of 53 short stature toddlers as a case and 53 normal toddlers as a control. The sampling technique for short stature toddlers was total sampling technique while the normal toddlers used simple random sampling. The data were analyzed using Chi-square test. Results: Most of the mothers with feeding care in the case group and control group were 27 (50.9\%) in the case group and 39 (73.6\%) in the control group. Most of the family's economic status in the case group was low or 33 $(62.3 \%)$, whereas in the control group most of the family's economic status was high or 35 (66.0\%). There was a correlation between parenting feeding $(p=0.016)$ and economic status $(p=0.004)$ with the occurrence of short stature toddlers. Conclusion: There is a correlation between feeding style with the occurrence of short stature. In addition, there is also a correlation between economic status and the occurrence of short stature children.
\end{abstract}

Keywords : Short stature toddlers; Feeding parenting; Economic status

\begin{abstract}
Abstrak
Latar Belakang : Balita Pendek masih menjadi permasalahan gizi di Indonesia yang belum terselesaikan karena prevalensinya yang masih tinggi. Pola asuh pemberian makan dan status ekonomi merupakan salah satu faktor yang menyebabkan terjadinya balita pendek. Tujuan : Penelitian ini bertujuan untuk menganalisis hubungan antara pola asuh pemberian makan dan status ekonomi dengan kejadian balita pendek usia 0-24 bulan di Desa Gunungwetan Wilayah Puskesmas Jatilawang Kabupaten Banyumas.

Metode : Penelitian ini menggunakan metode penelitian survei analitik dengan pendekatan kasus kontrol. Jumlah sampel yang digunakan adalah 106 responden yang terdiri dari kelompok balita pendek sebagai kasus (53), dan kelompol balita normal sebagai kontrol (53).Teknik pengambilan sampel untuk kelompok balita pendek menggunakan total sampling dan untuk kelompok balita normal menggunakan simple random sampling. Analisa data menggunakan uji Chi-square. Hasil : Ibu dengan pola asuh pemberian makan pada kelompok kasus dan kelompok kontrol sebagian besar baik sebanyak 27 (50,9\%) pada kelompok kasus dan 39 (73,6\%) pada kelompok kontrol. Status ekonomi keluarga pada kelompok kasus sebagian besar yaitu rendah sebanyak 33 (62,3\%), sedangkan pada kelompok kontrol sebagian besar status ekonomi keluarga yaitu tinggi sebanyak 35 (66,0\%). Terdapat hubungan antara pola asuh pemberian makan $(p=0,016)$ dan status ekonomi $(p=0,004)$ dengan kejadian balita pendek. Simpulan :
\end{abstract}


Terdapat hubungan pola asuh pemberian makan dengan kejadian balita pendek dan status ekonomi dengan kejadian balita pendek.

Kata Kunci : Balita pendek; Pola asuh pemberian makan; Status ekonomi

\section{PENDAHULUAN}

Berdasarkan (WHO, 2013) balita pendek adalah status gizi didasarkan pada indeks panjang badan menurut umur $(\mathrm{PB} / \mathrm{U})$ atau tinggi badan menurut umur $(\mathrm{TB} / \mathrm{U})$ dibandingkan dengan standar baku WHOMGRS (Multicentre Growth Reference Study) dengan batas (Zscore) kurang dari -2 SD. Berdasarkan data WHO, pada tahun 2017 sebesar 22,2\% atau sekitar 150,8 juta balita di dunia mengalami tubuh pendek stunting. Namun angka ini sudah mengalami penurunan jika dibandingkan dengan angka balita pendek pada tahun 2000 yaitu 32,6\% (Kemenkes RI, 2018). Indonesia termasuk ke dalam negara ketiga dengan prevalensi tertinggi di South-East Asia Regional (SEAR) (Kemenkes RI, 2017). Berdasarkan data Pemantauan Status Gizi (PSG) selama tiga tahun terakhir, balita pendek memiliki prevalensi tertinggi dibandingkan dengan masalah gizi lainnya seperti gizi kurang, kurus dan gemuk. Survei Pemantauan Status Gizi (PSG) didapatkan hasil balita pendek di Indonesia adalah 29\%. Angka ini mengalami penurunan pada tahun 2016 menjadi 27,5\% namun prevalensi balita pendek kembali meningkat menjadi 29,6 pada tahun 2017 (Kementrian Kesehatan RI, 2018).

Berdasarkan data yang diperoleh peneliti di Puskesmas Jatilawang pada tahun 2019 yang memiliki angka kejadian balita pendek usia 0-24 bulan paling tinggi terdapat di Desa Gunungwetan dengan jumlah 53 balita dari 147 balita yang telah dilakukan pengukuran panjang badan dengan hasil yang mengalami tubuh sangat pendek sebesar $11,6 \%$, dan tubuh pendek $24,49 \%$ dan yang tubuh normal sebesar 64 $\%$. Usia 0 - 24 bulan merupakan masa kehidupan yang sangat penting atau masa periode emas yang dikenal dengan "Golden
Age”, dimana pada masa balita anak perlu memperoleh perhatian yang serius karena pada masa ini merupakan tumbuh kembang pada anak, pola asuh orang tua sangat penting terutama dalam pemberian gizi seimbang karena menjadi pondasi tumbuh kembang anak yang optimal (Sakti dkk, 2013).

Pola asuh pemberian makan merupakan salah satu faktor yang menyebabkan terjadinya balita pendek, dikarenakan pola asuh makan yang diterapkan oleh ibu akan berpengaruh terhadap pertumbuhan dan perkembangan balita karena kekurangan gizi pada masa balita akan bersifat irreversible (tidak dapat pulih), sehingga pada masa ini balita membutuhkan asupan makan yang berkualitas (Martianto.,Riyadi.,\& Ariefiani, 2011). Faktor lain dari kasus balita pendek salah satunya adalah status ekonomi, status ekonomi keluarga merupakan penyebab tidak langsung dari kejadian balita pendek yang dipengaruhi oleh tingkat pendidikan orang tua, dan tingkat pendapatan keluarga, apabila akses pangan ditingkat rumah tangga terganggu, terutama akibat kemiskinan, maka penyakit kurang gizi (malnutrisi) seperti balita pendek pasti akan muncul (Adriani \& Wiryatmaji, 2012).

Berdasarkan hasil wawancara kepada pelaksana gizi Puskesmas Jatilawang, Penyebab utama masalah gizi pada balita yaitu asupan makanan dan penyakit infeksi. Hal ini dilihat dari rendahnya cakupan pemberian ASI Ekslusif, Praktik pemberian makan yang kurang teratur, kurangnya keaktifan kunjungan ke posyandu. Sementara itu berdasarkan 3 kader posyandu, penyebab balita mengalami tubuh pendek di desa Gunungwetan 
disebabkan oleh pemberian makan yang dilakukan ibu kurang tepat, pemberian makan ini terkait dengan jenis makanan yang diberikan kepada balita dan jumlah asupan makanan yang diberikan tidak sesuai dengan kebutuhan balita. Namun, saat ini pola asuh pemberian makan dengan kejadian balita pendek masih belum terbukti. Hasil wawancara kepada 6 Ibu balita pendek, 4 dari 6 ibu balita pendek mengatakan pola makan anaknya tidak teratur, sehari hanya makan 1 kali, dan jarang minum susu. Anak tersebut juga susah makanan sayuran, Sedangkan $2 \mathrm{ibu}$ balita pendek mengatakan sering memberikan makan anaknya yang mengandung protein seperti telur rebus dan ikan guna memperbaiki gizi anaknya, Tetapi jika ditambahkan sayuran anaknya tidak mau makan. Hasil wawancara kepada 6 ibu balita pendek tentang status ekonomi keluarga didapatkan ibu dari anak tersebut hanya menempuh pendidikan sampai Sekolah Dasar, dan dengan pendapatan keluarga berada di bawah upah minimum Kabupaten Banyumas (1.750.000/bulan). Ibu pada kenyataannya memberikan asupan gizi seadanya saja karena keterbatasan ekonomi.

Berdasarkan uraian diatas, penulis tertarik untuk meneliti hubungan antara pola asuh pemberian makan dan status ekonomi dengan kejadian balita pendek usia 0 - 24 Bulan di Desa Gunungwetan Wilayah Puskesmas Jatilawang Kabupaten Banyumas.

Tujuan penelitian ini untuk mengetahui hubungan pola asuh pemberian makan dan status ekonomi dengan kejadian balita pendek usia 0-24 bulan di Desa Gunungwetan Wilayah Puskesmas Jatilawang Kabupaten Banyumas.

\section{METODE PENELITIAN}

Penelitian ini menggunakan metode penelitian survei analitik dengan pendekatan kasus kontrol. Jumlah sampel yang digunakan adalah 106 responden yang terdiri dari 53 responden dalam kelompok balita pendek sebagai kasus, dan 53 responden dari kelompol balita normal sebagai kontrol.Teknik pengambilan sampel untuk kelompok balita pendek menggunakan total sampling dan untuk kelompok balita normal menggunakan simple random sampling. Tempat dan waktu penelitian dilaksanakan di Desa Gunungwetan pada bulan Desember 2019. Teknik analisis data menggunakan Uji Chi Square.

\section{HASIL DAN PEMBAHASAN}

1. Deskripsi Karakteristik Responden Tabel.1 Distribusi Jenis Kelamin, Usia Balita Pendek Dan Balita Normal

\begin{tabular}{lllll}
\hline \multirow{2}{*}{ Variabel } & \multicolumn{2}{l}{ Kasus } & \multicolumn{2}{l}{ Kontrol } \\
\cline { 2 - 5 } & $\mathrm{n}$ & $\%$ & $\mathrm{n}$ & $\%$ \\
\hline Jenis Kelamin & & & & \\
Laki-laki & 27 & 50,9 & 28 & 52,8 \\
Perempuan & 26 & 49,1 & 25 & 47,2 \\
Total & 53 & 100,0 & 53 & 100,0
\end{tabular}

Usia

0-12 bulan $\quad 25 \quad 47,2 \quad 41 \quad 77,4$

13-18 bulan $28 \quad 52,8 \quad 12 \quad 22,6$

$\begin{array}{lllll}\text { Total } & 53 & 100,0 & 53 & 100,0\end{array}$

Tabel 1 tentang karakteristik jenis kelamin responden menunjukan balita pendek (stunting) mayoritas berjenis kelamin laki- laki $(50,9 \%)$ daripada balita perempuan $(49,1 \%)$. 
Tabel 1 menunjukan bahwa menurut usia pada kelompok kasus (balita pendek) mayoritas terjadi pada balita usia 13-24 bulan (toddler) sebanyak $28 \quad(52,8 \%)$. Pada kelompok kontrol (balita normal) mayoritas usia 0-12 bulan (bayi) sebanyak $41(77,4 \%)$.

2. Deskripsi Pola Asuh Pemberian Makan

Tabel 2 Distribusi Frekuensi Pola Asuh Pemberian Pada Balita Pendek Dan Balita Normal

\begin{tabular}{lllll} 
& \multicolumn{2}{l}{ Kasus } & \multicolumn{2}{c}{ Kontrol } \\
\cline { 2 - 5 } $\begin{array}{c}\text { Pola asuh pemberian } \\
\text { makan }\end{array}$ & $\mathrm{n}$ & $\%$ & $\mathrm{n}$ & $\%$ \\
& & & & \\
\hline Kurang Baik & 26 & 49,1 & 14 & 26,4 \\
Baik & 27 & 50,9 & 39 & 73,6 \\
Total & 53 & 100,0 & 53 & 100,0 \\
\hline
\end{tabular}

Berdasarkan tabel 2 menunjukkan bahwa ibu memberikan pola asuh pemberian makan pada kelompok kasus (balita pendek) dan kelompok kontrol (balita normal) mayoritas baik sebanyak 27 $(50,9 \%)$ pada kelompok kasus (balita pendek) dan $39(73,6 \%)$ pada kelompok kontrol (balita normal).

\section{Deskripsi Status Ekonomi}

Tabel. 3 Distribusi Frekuensi Status Ekonomi Keluarga Pada Balita Pendek Dan Balita Normal

\begin{tabular}{cllll} 
& \multicolumn{2}{l}{ Kasus } & \multicolumn{2}{l}{ Kontrol } \\
\cline { 2 - 5 } $\begin{array}{l}\text { Status } \\
\text { ekonomi }\end{array}$ & $\mathbf{n}$ & $\%$ & $\mathbf{n}$ & $\mathbf{\%}$ \\
& & & & \\
\hline Rendah & 33 & 62,3 & 18 & 34,0 \\
Tinggi & 20 & 37,7 & 35 & 66,0 \\
Total & 53 & 100,0 & 53 & 100,0
\end{tabular}

Hasil penelitian menunjukkan bahwa keluarga yang status ekonominya rendah pada kelompok kasus (balita pendek) sebanyak $33(62,3 \%)$ lebih banyak daripada keluarga degan status ekonomi rendah pada kelompok kontrol (balita normal) sebanyak $18(34,0 \%)$.

4. Analisis Hubungan Pola Asuh Pemberian Makan Dengan Kejadian Balita Pendek

Tabel 4 Hubungan Pola Asuh Pemberian Makan Dengan Kejadian Balita Pendek Usia 0-24 Bulan

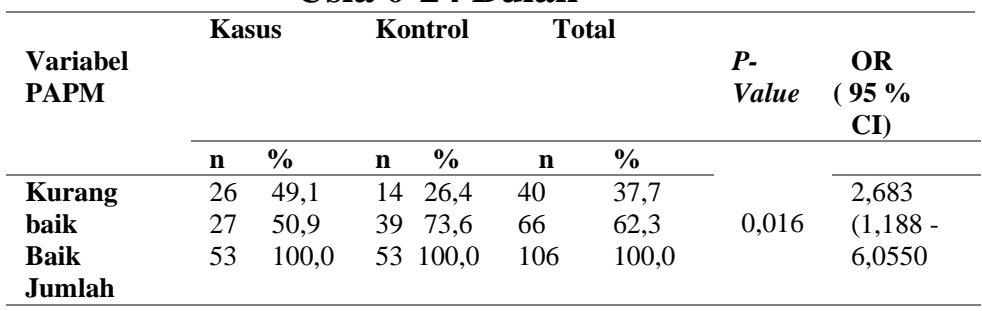

Berdasarkan hasil uji chi square didapatkan nilai p-value sebesar $0,016(\mathrm{P}<$ 0,05). Hal ini menunjukan bahwa ada hubungan yang signifikan antara pola asuh pemberian makan dengan kejadian balita pendek usia 0-24 bulan.

Nilai odd ratio yang diperoleh yaitu 2,683 (95\% CI = 1,188 - 6,055). Hal ini diartikan bahwa balita yang mendapatkan pola asuh kurang baik berpeluang 2,683 kali mengalami tubuh pendek (stunting) dibandingkan dengan balita yang mendapatkan pola asuh baik.

\section{Hubungan Status Ekonomi Dengan Kejadian Balita Pendek}

Tabel. 5 Hubungan Status Ekonomi Dengan Kejadian Balita Pendek Usia 0-24

\begin{tabular}{|c|c|c|c|c|c|c|c|c|}
\hline \multirow{2}{*}{$\begin{array}{l}\text { Status } \\
\text { Ekonomi }\end{array}$} & \multicolumn{2}{|c|}{ Kasus } & \multicolumn{2}{|c|}{ Kontrol } & \multicolumn{2}{|c|}{ Total } & \multirow{2}{*}{$\begin{array}{l}P \text { - } \\
\text { Value }\end{array}$} & \multirow{2}{*}{$\begin{array}{l}\text { OR } \\
(95 \% \\
\text { CI })\end{array}$} \\
\hline & $\mathbf{n}$ & $\%$ & $\mathbf{n}$ & $\%$ & $\mathbf{n}$ & $\%$ & & \\
\hline Rendah & 33 & 62,3 & 18 & 34,0 & 51 & 48,1 & \multirow{4}{*}{0,004} & \multirow{3}{*}{3,208} \\
\hline Tinggi & 20 & 37,7 & 35 & 66,0 & 55 & 51,9 & & \\
\hline Jumlah & 53 & 100,0 & 53 & 100,0 & 106 & 100,0 & & \\
\hline & & & & & & & & $\begin{array}{l}(1,449- \\
7,103)\end{array}$ \\
\hline
\end{tabular}

Berdasarkan hasil uji chi square diperoleh nilai $p$ - value sebesar $0,004(\mathrm{p}<$ 
0,05). Hal ini menunjukan bahwa ada hubungan antara status ekonomi dengan kejadian balita pendek usia 0-24 bulan.

Nilai odd ratio yang diperoleh yaitu 3,208 $(95 \%$ CI $=1,449-7,103$. Hal ini diartikan bahwa balita dengan status ekonomi keluarga yang rendah berpeluang 3,208 kali mengalami tubuh pendek (stunting) dibandingkan dengan balita yang status ekonomi keluarganya tinggi.

\section{PEMBAHASAN}

Hasil yang didapatkan pada penelitian balita pendek (stunting) mayoritas berjenis kelamin laki- laki $(50,9 \%)$ daripada balita perempuan $(49,1 \%)$. Hasil serupa juga ditemukan pada penelitian Aguayo, Nair, Badgaiyan, \& Krishna (2016) di India bahwa balita pendek (stunting) lebih banyak berjenis kelamin laki-laki $(25,40 \%)$ daripada balita perempuan $(19,30 \%)$ dan menyebutkan hasil analisis regresi multivariat menunjukan kemungkinan pendek (stunting) pada anak laki- laki lebih tinggi 38\% daripada anak perempuan. Jenis kelamin salah satu faktor yang mempengaruhi kejadian stunting pada balita. Perempuan lebih banyak mengandung lemak dalam tubuhnya yang berarti bahwa lebih banyak jaringan tidak aktif dalam tubuhnya meskipun berat badan yang sama dengan anak laki-laki. Energi yang diperlukan 10 persen lebih rendah dari laki- laki. Kebutuhan gizi anak lakilaki lebih besar dari perempuan (Kartasapoetra dan Marsetyo, 2008). Penelitian ini tidak sesuai dengan hasil yang ditemukan di Ghana bahwa hasil tersebut menunjukkan stunting lebih banyak terjadi pada anak perempuan dibandingkan laki-laki (Eunice dan Sarah, 2013). Namun dalam penelitian (Taguri,dkk, 2009) di Libya menunjukkan bahwa prevalensi stunting pada anak lakilaki lebih besar dibanding anak perempuan.
Kasus (balita pendek) mayoritas terjadi pada balita usia 13-24 bulan (toddler). Hal ini tidak sesuai dengan penelitian yang ditemukan oleh Nurmayasanti (2019) yang menyatakan bahwa usia balita yang paling banyak mengalami stunting adalah usia 3759 bulan yaitu sebanyak 30,4\% dan balita yang normal persentase paling banyak terlihat pada balita usia 37-59 bulan $(37,5 \%)$. Stunting terjadi pada kehidupan awal (0 - 2 tahun) dapat menyebabkan gangguan perkembangan kognitif, bahasa, dan motorik pada anak (Muhoozi,dkk,2016). Stunting mencerminkan masalah gizi sejak periode pertumbuhan dan perkembangan paling cepat sejak awal kehidupan (Mgoudet,2018). Kegagalan pertumbuhan sebagian besar terjadi dari tiga bulan hingga 18 sampai 24 bulan (Victora,2010). Penelitian ini juga didukung penelitian yang ditemukan Teshome (2009) yaitu proporsi stunting tertinggi ditemukan pada kelompok umur 13-24 bulan dan yang paling rendah pada kelompok umur 0-6 bulan.

Postur tubuh pendek (stunting) adalah peningkatan tinggi badan yang tidak sesuai dengan umurnya. Stunting indikator kekurangan gizi kronis akibat dari ketidakcukupan asupan makanan dan akibat dari ketidakcukupan asupan makanan dalam waktu lama, kualitas pangan yang buruk, meningkatnya morbiditas, atau kombinasi dari faktor tersebut (Kemenkes, 2011). Berat badan dapat menjadi indikator untuk melihat kemungkinan kelangsungan hidup, pertumbuhan, kesehatan jangka panjang dan psikologis anak. Penilaian status gizi secara antropometri pada bayi atau balita dengan mengukur berat badan, panjang badan, lingkar kepala, lingkar lengan adalah metode gizi untuk mengkaji pertumbuhan dan perkembangan balita yang sangat berpengaruh pada morbiditas 
dan motralitas bayi atau balita pada umur selanjutnya.

Hasil Penelitian menunjukan ibu memberikan pola asuh pemberian makan pada kelompok kasus (balita pendek) dan kelompok kontrol (balita normal) mayoritas baik sebanyak 27 (50,9\%) . Semakin baik pola pemberian makan seorang balita semakin baik pula status gizi balita tersebut, hal ini dikarenakan konsumsi makanan berpengaruh terhadap status gizi seseorang, makanan sehari-hari yang baik akan memberikan semua zat gizi yang dibutuhkan untuk tubuh, jadi bila konsumsi makanan seseorang baik maka status gizi akan baik pula begitu juga sebaliknya (Muzayyaroh,2017). Hasil penelitian yang ditemukan oleh Nurjanah (2018) mengungkapkan hasil yang tidak sama dimana proporsi balita yang mengalami tubuh pendek dan balita yang normal lebih banyak pada pola pemberian makan yang kurang yaitu $68(42,5 \%)$ pada balita pendek dan pada kelompok balita normal sebanyak $92(57,5 \%)$.

Hasil Penelitian menunjukkan bahwa keluarga yang status ekonominya rendah pada kelompok kasus (balita pendek) sebanyak 33 (62,3\%). Hasil penelitian sesuai dengan yang yang ditemukan Martha dan Budi (2014) bahwa proporsi balita yang mengalami gangguan pertumbuhan dalam tingkat sedang dan parah paling banyak berasal dari keluarga dengan tingkat ekonomi rendah. Penelitian (Picauly\& Toy, 2013) menyatakan bahwa tingkat ekonomi berpengaruh signifikan terhadap kejadian pendek pada balita. Menurut Dewi \& Hidayanti (2012) faktor ekonomi mempunyai peranan penting terhadap status gizi anak karena mempengaruhi kemampuan keluarga dalam membeli pangan. Keluarga dengan status ekonomi baik cenderung mampu menyediakan kualitas dan kuantitas pangan yang baik bagi anak.
Hasil uji statistik menunjukan bahwa pola asuh pemberian makan merupakan faktor risiko penyebab kejadian balita pendek pada anak usia 0-24 bulan. Pola asuh adalah keseluruhan interaksi orang tua dan anak, dimana orang tua yang memberi dorongan bagi anak dengan mengubah tingkah laku, pengetahuan dan nilai-nilai yang dianggap paling tepat bagi orang tua agar anak bisa mandiri, tumbuh, serta berkembang secara sehat dan optimal, memiliki rasa percaya diri, memiliki sifat rasa ingin tahu, bersahabat, dan berorientasi untuk sukses (Agency \& Tridhonanto, 2014). Jika ibu memberikan perhatian atau dukungan lebih terhadap anaknya dalam hal pola asuh pemberian makanan akan berpengaruh positif kepada keadaan status gizi anaknya, namun sebaliknya jika ibu tidak memperhatikan pola asuh pemberian makan terhadap anaknya, maka itu akan berdampak negative terhadap status gizi anaknya. Hasil penelitian yang ditemukan oleh Sari \& Ratnawati (2006) sama dengan penelitian ini yang menyatakan bahwa ada hubungan antara praktik pemberian makan kepada balita dengan status gizi. Pemberian makanan pada balita merupakan landasan yang penting dalam proses pertumbuhan. Di seluruh dunia sekitar 30\% anak dibawah lima tahun yang mengalami stunting merupakan konsekuensi dari praktik pemberian makan yang buruk dan infeksi berulang (WHO,2017) .

Hasil penelitian menunjukan bahwa status ekonomi merupakan faktor penyebab kejadian balita pendek pada anak usia 0-24 bulan. Keadaan ekonomi keluarga yang baik dapat menjamin terpenuhinya kebutuhan gizi keluarga. Semakin tinggi status ekonomi, semakin baik pula status gizi suatu keluarga. Lain hal dengan kemiskinan, kemiskinan selalu berkaitan dengan kekurangan makanan serta kesehatan lingkungan yang jelek dan dalam keadaan serba tidak tahu, hal ini dapat 
menghambat upaya peningkatan pertumbuhan pada anak (Depkes RI, 2006).

Hasil penelitian ini serupa dengan penelitian sebelumnya yang menyatakan bahwa ada hubungan yang bermakna antara status ekonomi keluarga dengan kejadian stunting. Balita yang status ekonomi keluarga tergolong rendah memiliki risiko sebesar 2 kali untuk mengalami stunting dibandingkan balita yang status ekonomi keluarga tinggi (Ai syah, 2012). Status ekonomi keluarga yang rendah mempengaruhi kualitas maupun kuantitas bahan makanan yang dikonsumsi oleh keluarga. Makanan yang didapat biasanya kurang bervariasi dan sedikit jumlahnya terutama pada bahan pangan yang berfungsi untuk pertumbuhan anak seperti sumber protein, vitamin dan mineral, sehingga meningkatkan risiko kurang gizi. Keterbatasan ini meningkatkan risiko terjadinya stunting pada anak balita (Astari, Nasoetion \& Dwiriyani, 2005).

\section{SIMPULAN}

Karakteristik responden berdasarkan jenis kelamin pada balita pendek lebih banyak berjenis kelamin laki-laki sebanyak 27 $(58,7 \%)$ dan pada balita normal lebih banyak berjenis kelamin laki-laki sebanyak 28 (52,8\%). Usia pada kelompok kasus (balita pendek) banyak terjadi pada usia 1324 bulan (toddler) sebanyak 28 (52,8 \%), pada kelompok kontrol (balita normal) mayoritas usia 0-12 bulan sebanyak 41 $(77,4 \%)$.

Ibu memberikan pola asuh pemberian makan pada kelompok kasus (balita pendek) dan kelompok kontrol (balita normal) mayoritas baik sebanyak $27 \%(50,9 \%)$ pada kelompok kasus (balita pendek) dan 39 (73,6\%) pada kelompok kontrol (balita normal). Kelurga dengan Status ekonomi rendah pada kelompok kasus (balita pendek) mayoritas rendah sebanyak 33 (62,3\%). Pada kelompok kontrol (balita normal) mayoritas status ekonomi tinggi keluarga tinggi sebanyak 35 $(66,0 \%)$.

Ada hubungan pola asuh pemberian makan ( $P$-value $=0,016)$ dan Status ekonomi $(P$-value $=0,004)$ dengan kejadian balita pendek usia 0-24 bulan di Desa Gunungwetan Wilayah Puskesmas Jatilawang Kabupaten Banyumas.

\section{UCAPAN TERIMAKASIH}

Terima kasih atas suport kepala Puskesmas Jatilawang yang memberikan ijin kepada peneliti sehingga dapat melakukan penelitian di wilayah kerja Puskesmas Jatilawang. Terima kasih kepada tenaga kesehatan di wilayah kerja Puskesmas Jatilawang yang telah membantu dalam proses pengumpulan data dalam penelitian ini.

\section{REFERENSI}

1. Adriani dan Wirjatmadi. (2012). Peranan Gizi dalam Siklus Kehidupan. Jakarta: Kencana.

2. Agency \& Tridhonanto. (2014). Mengembangkan Pola Asuh Demokratis. Jakarta: Gramedia.

3. Aguayo., Nair., Badgaiyan., \& Krishna. (2016). Determinants of stunting and poor linear growth in children under 2 years of age in India: an in-depth analysis 
of Maharashtra's comprehensive nutrition survey. Maternal \& Child Nutrition, 12(1): 121-140.

4. Aisyah. (2012). Faktor-faktor yang berhubungan dengan kejadian stunting pada balita 24-59 bulan di perkotaan Jawa Timur (Analisis data Riskesdas 2010). Skripsi. Depok: FKM UI.

5. Astari, Nasoetion, Dwiriani. (2005). Hubungan Karakteristik Keluarga, Pola Pengasuhan dan Kejadian Stunting Anak Usia 6-12 Bulan. Media Gizi dan Keluarga, 29 (2): 40-46.

6. Departemen Kesehatan Republik Indonesia. (2006). Pedoman pelaksanaan stimulasi, deteksi, dan intervensi dini tumbuh kembang anak di tingkat pelayanan kesehatan dasar. Jakarta: Bakti Husada.

7. Eunice, A and D. Sarah. (2013). An Assesment of Nutritional Status of Under Five Children in Four District in The Central Region of Ghana. Asian Journal of Agriculture and Rural Development, 3 (11): 851-860.

8. Kartasapoetra dan Marsetyo. (2008). Ilmu Gizi Korelasi Gizi dan Produksi Kerja. Jakarta: Rineka Cipta.

9. Kementrian Kesehatan RI. (2018). Buletin Jendela Data Dan Informasi Kesehatan. Jakarta : Kemenkes RI.
10. Kementrian Kesehatan RI. (2018). Hasil Riset Kesehatan Dasar Tahun 2018. Jakarta : Kemenkes RI.

11. Martha dan Budi. (2014). Faktor soisal ekonomi gangguan pertumbuhan anak 059 bulan : Riskesdas Tahun 2010. Artikel Publikasi. FKM UI.

12. Martianto D., Riyadi H., Ariefiani R. (2011). Pola Asuh Makan Pada Rumah Tangga Yang Tahan Dan Tidak Tahan Pangan Serta Kaitannya Dengan Status Gizi Anak Balita Di Kabupaten Banjarnegara. J Gizi dan Pangan; 6 (1):51-58.

13. MGoudet, S., Griffiths, P. L., Bogin, B. A. \& Madise, N. J. (2018). Nutritional interventions for preventing stunting in children ( 0 to 5 years ) living in urban slums in low and middle-income countries (LMIC) (Protocol). Cochrane Database of Systematic Rev. doi:10.1002/14651858.CD011695.www. cochran elibrary.com 